This item was submitted to Loughborough's Research Repository by the author.

Items in Figshare are protected by copyright, with all rights reserved, unless otherwise indicated.

\title{
Japan: The banks are back! Or are they?
}

PLEASE CITE THE PUBLISHED VERSION

PUBLISHER

(c) Loughborough University

VERSION

VoR (Version of Record)

LICENCE

CC BY-NC-ND 4.0

REPOSITORY RECORD

Hall, Maximilian J.B.. 2019. "Japan: The Banks Are Back! or Are They?". figshare. https://hdl.handle.net/2134/4176. 
This item was submitted to Loughborough's Institutional Repository (https://dspace.lboro.ac.uk/) by the author and is made available under the following Creative Commons Licence conditions.

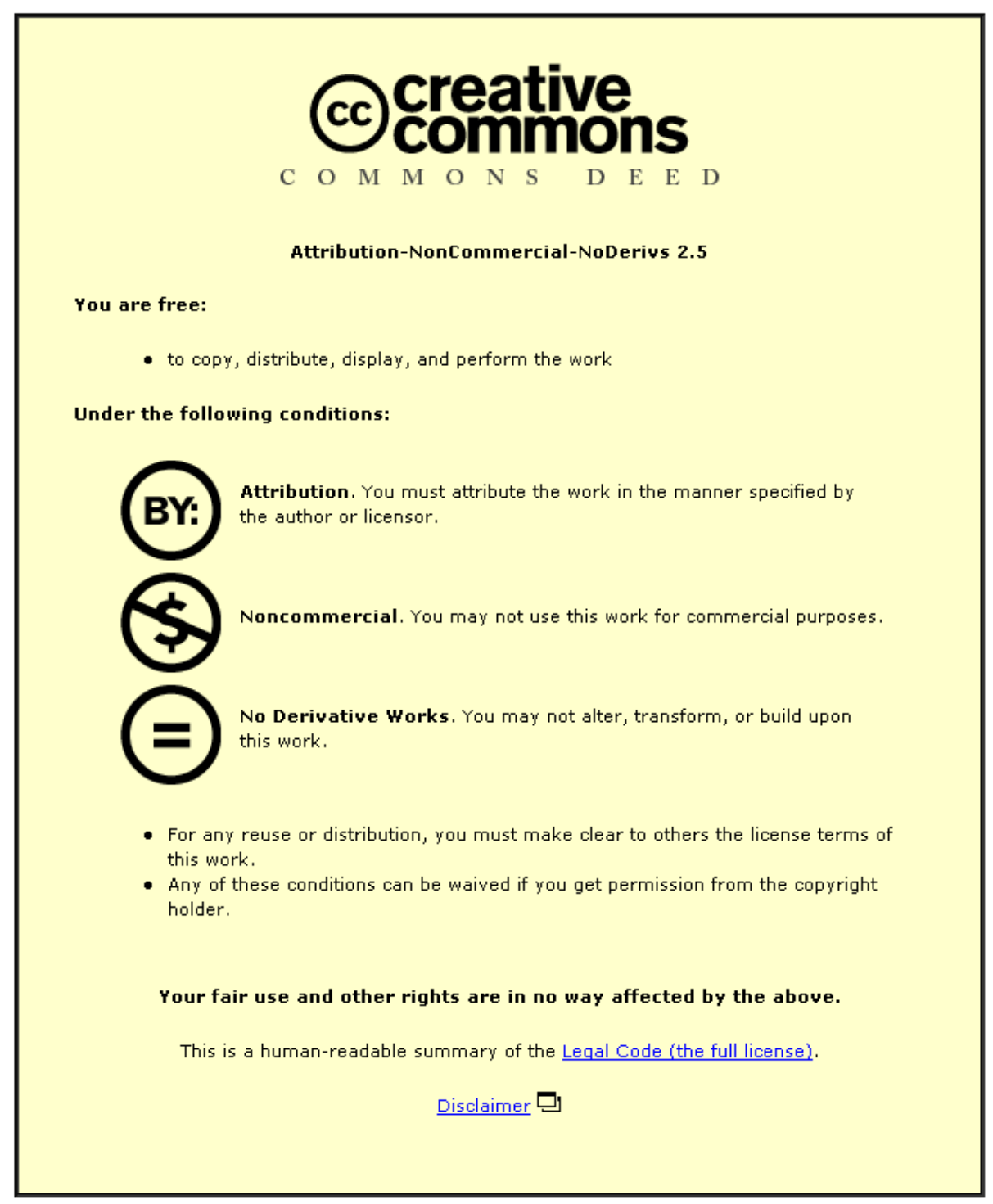

For the full text of this licence, please go to: http://creativecommons.org/licenses/by-nc-nd/2.5/ 
ISSN 1750-4171

\section{DEPARTMENT OF ECONOMICS}

\section{DISCUSSION PAPER SERIES}

Japan: The banks are back! Or are they?

Maximilian J. B. Hall

WP 2008 - 05

Dept Economics

Loughborough University

Loughborough

LE11 3TU United Kingdom

Loughborough

Tel: + 44 (0) 1509222701

Fax: + 44 (0) 1509223910

http://www.lboro.ac.uk/departments/ec 


\section{"JAPAN : THE BANKS ARE BACK! OR ARE THEY?"*}

by

Dr. Maximilian J. B. Hall

Professor of Banking and Financial Regulation

Department of Economics

Loughborough University

June 2008

*The financial support of the Daiwa Anglo-Japanese Foundation is gratefully acknowledged. 


\section{ABSTRACT}

Since fiscal 2003, the 'performance' of the Japanese banking sector, in terms of profitability, asset quality, and capital adequacy, has improved markedly as the real economy has recovered, suggesting that the widespread pessimism (see, for example, Hall, 2006 and IMF, 2003) expressed earlier concerning the fragility of the sector was somewhat overdone. Yet, despite these positive developments, a number of serious challenges still face the Japanese banking industry and their supervisors. Core profitability, for example, remains very weak, in part due to wafer thin lending margins at home and sluggish corporate loan demand. Asset quality has also widely suffered because of exposure to the re-regulated consumer finance industry and the US sub-prime market. And controversy still surrounds the issues of bank "under-reserving" and regulatory tolerance of "double gearing" on the capital adequacy front. These, and other, problems must be resolved if Japanese banks are to finally re-claim the ground lost to international competitors over the last 15 years or so and secure lasting improvement in their financial health.

JEL Classification: G21; G28; G32.

Keywords: Japanese Banking; Performance - Capital Adequacy and Profitability; Supervision; Financial Stability. 


\section{INTRODUCTION}

Apart from turning the tide on the non-performing loan (NPL) front, most performance indicators at the end of fiscal 2002 (i.e. at end-March 2003) painted a fairly bleak portrait of the Japanese banking sector. Return on assets and on equity were negative; core and net capital were in steady decline, with deferred tax assets (DTAs) assuming a growing share of core capital; and the sector was heavily exposed to equity risk, credit risk and interest rate risk (IMF, 2003; Hall, 2006). At end-March 2004, however, five of the top seven banking groups (UFJ Holdings and Resona Holdings - Resona Bank had to be rescued by the Government in May 2003 - were the odd ones out) posted net profits for the first time in three years, with the sector returning to overall profitability in fiscal 2004. And the following year, record profits were recorded by the banking industry. This remarkable turnaround, together with the associated reduction in financial fragility, are analysed in more detail below, together with the formidable problems still besetting the sector.

The paper is structured as follows. The next section reviews the structure of the Japanese banking sector as it stood at end-March 2007 following further consolidation and rationalisation. Section 3 analyses the latest trends in bank 'performance', in terms of profitability, asset quality and capital adequacy. Section 4 looks at the challenges still facing the sector. And Section 5 summarises and concludes. 


\section{THE STRUCTURE OF THE JAPANESE DEPOSIT-TAKING SECTOR}

As shown on Exhibit 1, at end-March 2007 there were over 200 banks proper operating in Japan with more than 1,500 cooperative-type institutions also active as deposit-takers. The former group comprised 6 City Banks, 64 Regional Banks, 46 Second Association Regional Banks, 65 Foreign Banks, 21 Trust Banks and 10 'others'. Continued consolidation amongst the major banks has meant that 4 major banking groups Mitsubishi UFJ, Mizuho, Sumitomo Mitsui and Resona - now dominate the banking scene in Japan (see Exhibit 2), with the 'Long-Term Credit Bank' categorisation finally disappearing as a separate sub-group. [For a discussion of the operations performed by the various categories of bank and co-operative see Japanese Bankers' Association, 2001.] 


\section{RECENT TRENDS IN BANK PERFORMANCE}

\subsection{Profitability}

As can be seen from Exhibit 3, the banking industry's performance was dire between fiscal 1995 and 2002, largely as a result of the collapse of Japan's asset price bubble and stagnation in the real economy. Indeed, during this period, net losses were recorded for each of the years 1995, 1997, 1998, 2001 and 2002. Whilst lending margins and gross profits remained fairly stable, net operating profits were negative from fiscal 1993 onwards because of the impact of disposing of huge amounts of NPLs on "loan losses". The fall in the value of securities held and the introduction of mark-to-market accounting also meant that, after fiscal 2001, banks were unable to boost profits by realising capital gains.

With the pick-up in the real economy (albeit at a sluggish pace) from 2003, largely due to export-led recovery because of a low exchange rate, and knock-on effects for corporate Japan and the stock market, the banking sector's fortunes began to improve. Although the sector, overall, did not return to profitability until fiscal $2004,{ }^{i}$ with the major banks reporting positive net income for the first time in 4 years and the regional banks for the first time in 10 years, 5 of the top 7 banking groups had, in fact, reported net profits in fiscal 2003, as noted in the introduction. Continued economic recovery during 2004/05, ${ }^{\text {ii }}$ a return to positive bank lending ${ }^{\text {iii }}$ and cessation of deflation ${ }^{\text {iv }}$ contributed to a record profits performance by the sector in fiscal 2005 as loan losses fell dramatically and a recovery in stock prices allowed for the realisation of capital gains again. Fiscal 2006 saw the industry reporting very healthy, ${ }^{\mathrm{v}}$ if slightly lower - because of a slight decrease in interest margins, a fall in non-interest income and an increase in credit costs associated with exposures to 
the consumer finance industry as a result of changes in the law relating to the so-called usurious (although the legal maximum was retrospectively cut to 29.2 per cent, borrowers were seeking refunds on loans charging over 20 per cent) 'grey zone loans' (see Bank of Japan, 2007, for a more detailed analysis - profits. But, in fiscal 2007, sharply lower profits were reported due mainly to the continuing impact of exposures to the consumer finance industry (i.e. loans to and investments in consumer finance companies, consumer credit companies and credit card companies) and, for some, to the US sub-prime market ${ }^{\mathrm{vi}}$ (see Bank of Japan, 2008).

\subsection{Asset Quality}

The trend in the Japanese deposit-taking sector's "bad" (i.e. "risk management") loans is clearly indicated in Exhibit 4. Hitting a peak of $¥ 53$ trillion at end-March 2002, it was down to ¥18.4. trillion by end-March 2007. In part, this reflects the success of the FSA's plan to force the major banks to halve their NPL ratios between end-March 2002, when the combined ratio stood at 8.4 per cent, and end-March 2005. As demonstrated in Exhibit 5, the major banks' combined ratio was down to 2.9 per cent by end-March 2005, with further declines taking it down to 1.5 per cent by end-March 2007, a level maintained at end-September 2007, the latest date for which figures are available (FSA, 2008). At 3.9 per cent, the latest figure for the regional bank grouping also represents a substantial improvement on the recent past (it was 7.8 per cent at end-March 2003, for example), although some regional banks are still operating with ratios substantially in excess of this figure. The performance during fiscal 2007, however - as noted above - is likely to reverse this declining trend somewhat, but hopefully only temporarily. 


\subsection{Capital Adequacy}

Despite all groups of banks posting figures demonstrating compliance with capital adequacy requirements, be they of the risk-adjusted type applied to internationally-active banks under the risk assets ratio (minimum 8 per cent) methodology of the Basel Accord or of the type applied to domestic-only operators (where a 4 per cent minimum ratio applies), this apparently happy state of affairs masked serious problems during the postbubble era. As shown in Exhibit 6: core capital was in steady decline between 1995 and 1998 and again between 2001 and 2003, reflecting the decline in the banks' profitability and the inability to issue common stock, at a reasonable price, because of the declining value of a bank franchise; net capital (i.e. after allowing for post-tax revaluation gains on securities held) was likewise in steady decline between 1994 and 1998 and again between 2000 and 2003, reflecting gyrations in the value of their securities; after 1998, DTAs represented a significant proportion of net capital; and, following capital injections by the Deposit Insurance Corporation (DIC) towards the end of the century in an attempt to stabilise the banking and financial sectors (see Hall, 2006), from 1999 a significant chunk of core equity capital was held by the Government reflecting the degree of 'nationalisation' instituted by the authorities. Since 2003, however, these problems have become less important. The recovery in bank profitability has put core and net capital on an upward trend since 2003. DTAs as a proportion of capital are now much less significant. ${ }^{\text {vii }}$ And the proportion of privately-held net capital has increased since 2003 as banks have repaid some of the earlier DIC capital injections. ${ }^{\text {vii }}$

Notwithstanding these undoubted improvements in both the quality and quantity ${ }^{\text {ix }}$ of bank capital at a time when exposures to credit risk, interest rate risk and market risk (incurred through stock holdings) were also generally falling ${ }^{\mathrm{x}}$ - thereby reducing overall 
financial fragility - some questions remain about the capital adequacy assessment regime. These are addressed in the next section. 


\section{CHALLENGES STILL FACING THE JAPANESE BANKING SECTOR}

\subsection{Profitability}

Despite the recent improvements in profitability noted in section 3.1, which saw major banks achieving a return on equity (ROE) of 16 per cent in fiscal 2005 - almost on a par with major US/EU banks - compared with a figure of over 7 per cent posted by regional banks, this has resulted mainly from the sharp reduction in credit costs enjoyed as a result of the reduced need to make allowance for loan losses once the NPL problem came under control. This has led economists at the Bank of Japan to develop a profitability measure that excludes volatile factors, such as credit costs, gains/losses on securities and corporate income tax payments. Their preferred measure (see Hattori et al., 2007), is "core ROE", where the above-mentioned volatile items are stripped out of ROE, defined as net income as a proportion of common stock plus preferred stock. Using this measure of profitability, the major banks as a group (there is large discrepancy between individual banks) are shown to have secured only a slight increase - from 0.7 per cent to 1.7 per cent - in profitability between fiscal 2003 and fiscal 2005, with the regional banks failing to show any improvement! For the major banks, the limited increase in core ROE was due to net income increasing by only fractionally more than equity. This, in turn, was mainly due to a fall in net interest income (the fall in interest income from loans exceeding the rise from securities) offsetting, to a degree, the increase enjoyed in non-interest income (e.g. from fees and commissions). The regional banks somewhat poorer performance reflected their slower growth in non-interest income for, whereas both groups of banks enjoyed increased fee income from the sale of mutual funds and pension/insurance policies, the major banks also enjoyed significant contributions from the origination of syndicated loans and the provision of commitment lines. 
The above analysis highlights the main factors still adversely impacting on bank profitability. For, although positive ROAs and ROEs are once again the norm, core ROEs are very low, both in absolute terms and relative to EU/G10 banks (see Bank of Japan, 2007, pp.47-50), because of weak growth in interest income - due to anaemic corporate loan demand and an inability to expand lending margins in a low nominal interest rate and highly competitive environment - and, for many, limited success in diversifying away from traditional lending activities. ${ }^{\mathrm{xi}}$ Moreover, attempts to raise investment returns by diversifying away from stocks and bonds ${ }^{\mathrm{xii}}$ (e.g. into structured products - such as RMBs, including those originated in Japan - credit products and hedge funds) have been shown to be fraught with danger; witness the fallout from the sub-prime turmoil discussed earlier.

In the face of such difficulties, banks will need to try and boost profits earnt on their core business by improving their management of credit risk, ${ }^{\text {xiii }}$ restraining the increase in credit costs, raising lending margins and re-enforcing their fee-generating business (Hattori et al., 2007). Whilst the last two remedies will not prove easy in the current market environment, ${ }^{\text {xiv }}$ especially for regional banks given the major banks incursion into their traditional territory and the growing importance of the Japan Post Bank, the Post Office's new banking arm, ${ }^{\mathrm{xv}}$ they are essential components of an integrated strategy that should seek to identify comparative advantage and market demands and then deliver the chosen services in the most cost-effective way possible. For some, this may necessitate structural re-organisation to enable group capital to be used more efficiently (Bank of Japan, 2007). Whatever strategies are adopted, management expertise will be at a premium in the brave new world. 
From a policy perspective, the imperatives are to nurture the recovery in the real economy, to try to engineer a generalised recovery in land prices and to promote the efficiency and competitiveness of the Japanese banking sector through deregulation. ${ }^{\text {xvi }}$ Further rationalisation within the regional bank sector should also be encouraged as some highly inefficient operators still exist, protected by the monopolistic practices still evident within the prefectural system.

\subsection{Asset Quality}

While the recent decline in NPL ratios, for both the major bank grouping and (most of) the regionals, towards international norms is to be applauded, the losses incurred on exposures to the consumer finance industry and on sub-prime-related products are a reminder of how quickly events can change. Risk management skills and policies must be up-rated if future losses on loans and investments are to be held to acceptable levels.

\subsection{Capital Adequacy}

Notwithstanding the recent increases achieved in both the quantity and quality of bank capital noted in section 3.3 above, a number of reservations remain concerning the capitalisation of Japanese banks. With respect to compliance with the BIS "rules", a stricter interpretation would see: some of the banks' loan loss provisions, currently classified as general but which, in reality, are specific, being fully deducted from capital; a greater proportion of cross-shareholdings being deducted from capital (to overcome the problem of "double gearing"); and further restrictions being placed on the inclusion of DTAs in core capital. Moreover, a more realistic view needs to be taken by some banks of the value of loan collateral and borrowers' capacity to repay, as reflected in NPL 
classifications and hence provisioning, ${ }^{\text {xvii }}$ a move which would further deplete reported bank capital ratios. 


\section{SUMMARY AND CONCLUSIONS}

Since fiscal 2003, the 'performance' of the Japanese banking sector has improved markedly, in tandem with that of the real economy. Record profits were revealed in fiscal 2005, with results for fiscal 2006 showing only a small fall from this peak, although results for fiscal 2007 were disappointing. Similarly, asset quality has generally improved, with non-performing loan (NPL) ratios now well below the historic highs recorded at endMarch 2002, and market risks now somewhat lower than when the IMF conducted its infamous 'Financial Stability Assessment Programme' stress tests back in 2003. Moreover, bank capital adequacy has generally improved, with both 'Tier 1' ratios and overall, BIS risk-adjusted ratios (now Basel II compliant) typically approaching international norms and being comfortably in excess of regulatory requirements. And the quality of capital has also increased with less reliance now being placed on deferred tax assets as a source of capital.

Yet things are not as healthy as this image portrays. Core profitability, once volatile factors such as credit costs are stripped from the figures, remains very weak, both in absolute terms and relative to EU/G10 averages. Lending margins remain wafer thin. Loan demand, most especially from corporates, is still sluggish. Land prices have yet to see a generalised recovery. And diversification from traditional lending activities is still limited, fee and commission income at the major banks, for example, accounting for around only 20 per cent of operating income. Similarly, with respect to asset quality, exposures to the US sub-prime market have delivered investment losses for some whilst exposures to the consumer finance industry since the passage of legislation concerning usurious "grey loans" have caused nasty blips in both NPL ratios and credit costs. Moreover, the issues 
surrounding continued "under-reserving" and regulatory tolerance of "double gearing" mitigate, to a degree, the successes achieved on the capital adequacy front. Overall, however, the Japanese banking sector appears to be firmly "back on track", following its abysmal performance during the "lost decade", now boasting some of the largest banks (by assets size) in the world, if not yet by return on equity! The continuing challenges faced in intensely competitive domestic and international markets are, however, well understood. And rising nominal interest rates along with improved risk management capabilities are likely to deliver increasing benefits in the medium to long term. 


\section{Endnotes}

Although Exhibit 3 actually shows the sector returning to profitability in fiscal 2003 because of a difference in coverage of institutions.

ii Real GDP grew by 2.8 per cent in 2005 and has remained positive since 2003.

iii Bank lending rose, for the first time in seven years, in August 2005.

iv The Core Consumer Price Index, which excludes perishable foods but includes fuel costs, returned to a positive level in November 2005, rising by 0.5 per cent in the 12 months to end-March 2006. By endMarch 2008, the index had reached a 10-year high of 1.2 per cent due to rising food and energy prices but, stripping these items out, left a figure of only 0.1 per cent (and the GDP deflator was still minus 1 per cent).

v Assisted by the removal of the competitive advantages enjoyed by the Postal Savings System and Postal Life-Insurance through privatisation, and by the privatisation/scaling back of the operations of other government-sponsored financial institutions (Fukao, 2007).

vi At the end of January 2008, the major banks reported net losses on sub-prime-related products for the first nine months of fiscal 2007 of $¥ 600$ billion, with the big three groups - Mizuho, MUFJ and SMFG reporting net losses of $¥ 345$ billion, $¥ 55$ billion and $¥ 99$ billion respectively. In May 2008, however, when the full year's figures were released, the major banks' combined losses on such products were revealed to be $¥ 863$ billion, with Mizuho, MUFJ and SMFG recording losses of $¥ 645$ billion, ¥125 billion and $¥ 93$ billion respectively. For Mizuho and MUFG, these losses contributed to recorded falls in net profits for fiscal 2007 of 49.8 per cent and 27.7 per cent respectively. SMFG, however, managed to marginally boost full year net profits, by 4.6 per cent; whilst the Resona Group, despite steering clear of sub-prime problems, still suffered a 55 per cent fall in net profits. For Mizuho, the bulk of whose subprime trades were booked through its brokerage office in London, the sub-prime-related losses resulted in the bank recording its first quarterly loss for five years.

vii Due, in part, to the introduction of a limit in March 2006 - 40 per cent of BIS core capital. This limit was then reduced to 20 per cent in March 2008.

vii By end-June 2007, ¥8.8 trillion of the near $¥ 12$ trillion of capital injections had been repaid by the banking sector, the three mega banking groups having already fully repaid during fiscal 2006.

ix The transition to a Basel II basis of assessment for internationally-active banks had little impact on reported ratios, although it did reduce risk-weighted assets for some (Bank of Japan, 2007). Most of the major banks adopted the foundation IRB approach, duly reporting overall risk-adjusted ratios of 12 per cent plus at end-March 2007, with Tier 1 ratios in excess of 7 per cent. [The corresponding figures for regional banks were 10 per cent and 8 per cent respectively.]

x The 'infamous' stress tests conducted by the IMF in 2002 and 2003 (see IMF, 2003) showed how seriously exposed the sector at that time was to equity risk, interest rate risk and credit risk, especially if DTAs are stripped out of shareholders' equity.

xi For the major bank grouping, fee and commission income represented only 20 per cent of operating income in fiscal 2006, with income from trading (e.g. forex and derivatives) and other sources amounting to 5 per cent and 27 per cent of total operating income respectively. This meant that the group's reliance on interest income (from loans and securities investments) had shrunk between fiscal 2002 and fiscal 2006 as its share of total operating income fell from 57 per cent to 49 per cent.

As far as lending activities are concerned, in the face of weak demand from their traditional customers - large corporates - the banks have diversified into M\&A and real estate financing, and the provision of housing loans to individuals and loans to SMEs. Moreover, some have returned to overseas markets in the quest for greater returns, with MUFG and SMFG seeking increased exposure through strategic investments in Merrill Lynch (MUFG has a \$1.2 billion stake) and Vietnam's Export-Import Commercial Joint Stock Bank (SMFG has a 15 per cent stake) respectively.

xii 'Alternative investments' accounted for nearly 10 per cent of the total balance of 'securities and monetary claims bought' for the major banks at end-September 2007, with the regional's share standing at 7 per cent.

xii Through, for example, using more sophisticated credit-scoring techniques and portfolio credit risk models, making use of credit bureaus and adopting an integrated risk management approach.

xiv Although a rise in market interest rates - policy rates are still at 0.5 per cent - would produce an adverse impact on bank profitability in the short run, because of the induced decline in the market value of bond portfolios, in the medium term it is likely to improve bank profitability by raising net interest margins, especially for the major banks. 
xv It has over $¥ 189,000$ billion in deposits and a network of 24,000 branches, making it the world’s largest bank on both counts.

xvi Introduction of the so-called "Second Big Bang" set of reforms (see FSA, 2007), embracing, amongst other things, proposals to lower the firewalls between banking and broking, is currently being held up because of a hung Parliament, with little legislative action now envisaged until January 2008 at the earliest.

xvii See Fukao, 2007 (Table 6) for an estimate of "under-reserving" during the fiscal 1997 to fiscal 2005 period (e.g. at end-March 2006, estimated under-reserving amounted to $¥ 8.3$ trillion compared with a private net (core) capital account balance of $¥ 21.5$ trillion). 


\section{REFERENCES}

Bank of Japan (2007), Financial System Report, Tokyo, September

Bank of Japan (2008), Financial System Report, Tokyo, March

Financial Services Agency (2007), 'FSA Publishes the Plan for Strengthening the Competitiveness of Japan's Financial and Capital Markets', Press Release, Tokyo, December

Financial Services Agency (2008), The Status of Non-Performing Loans as of EndSeptember 2007, Tokyo, February

Fukao, M. (2007), 'Financial Crisis and the Lost Decade', Asian Economic Policy Review, Vol.2, pp.273-297

Hall, M.J.B. (2000), 'What is the Truth About the Scale of Japanese Banks' Bad Debts? Is the Situation Manageable?', Journal of Financial Services Research, Vol.17, No.1, pp.69-91, February

Hall, M.J.B. (2006), 'The Japanese Banking System in the $21^{\text {st }}$ Century', Special Issue of Papeles de Economica Espanola on 'Comparative Financial Systems', Vol.110, pp.145-165, Madrid, December

Hattori, M., Ide, J. and Miyake, Y. (2007), 'Bank Profits in Japan from the Perspective of ROE Analysis', Bank of Japan Review Paper, 2007-E-3, Tokyo, March

IMF (2003), 'Japan: Financial System Stability Assessment and Supplementary Information', IMF Country Report No.03/287, Washington, December

Japan Center for Economic Research (2003), Profitability of Corporate, Banking and Life Insurance Sectors (in Japanese), Financial Research Report No.8, Tokyo

Japanese Bankers' Association (2001), The Banking System in Japan, Tokyo, March

Japanese Bankers' Association (2004), Japanese Banks, 2004, Tokyo

Japanese Bankers' Association (2005), Japanese Banks, 2005, Tokyo

Japanese Bankers' Association (2006), Japanese Banks, 2006, Tokyo

Japanese Bankers' Association (2007), Japanese Banks, 2007, Tokyo 


\section{EXHIBIT 1 : CATEGORISATION OF PRIVATE DEPOSITORY INSTITUTIONS OPERATING IN JAPAN*}

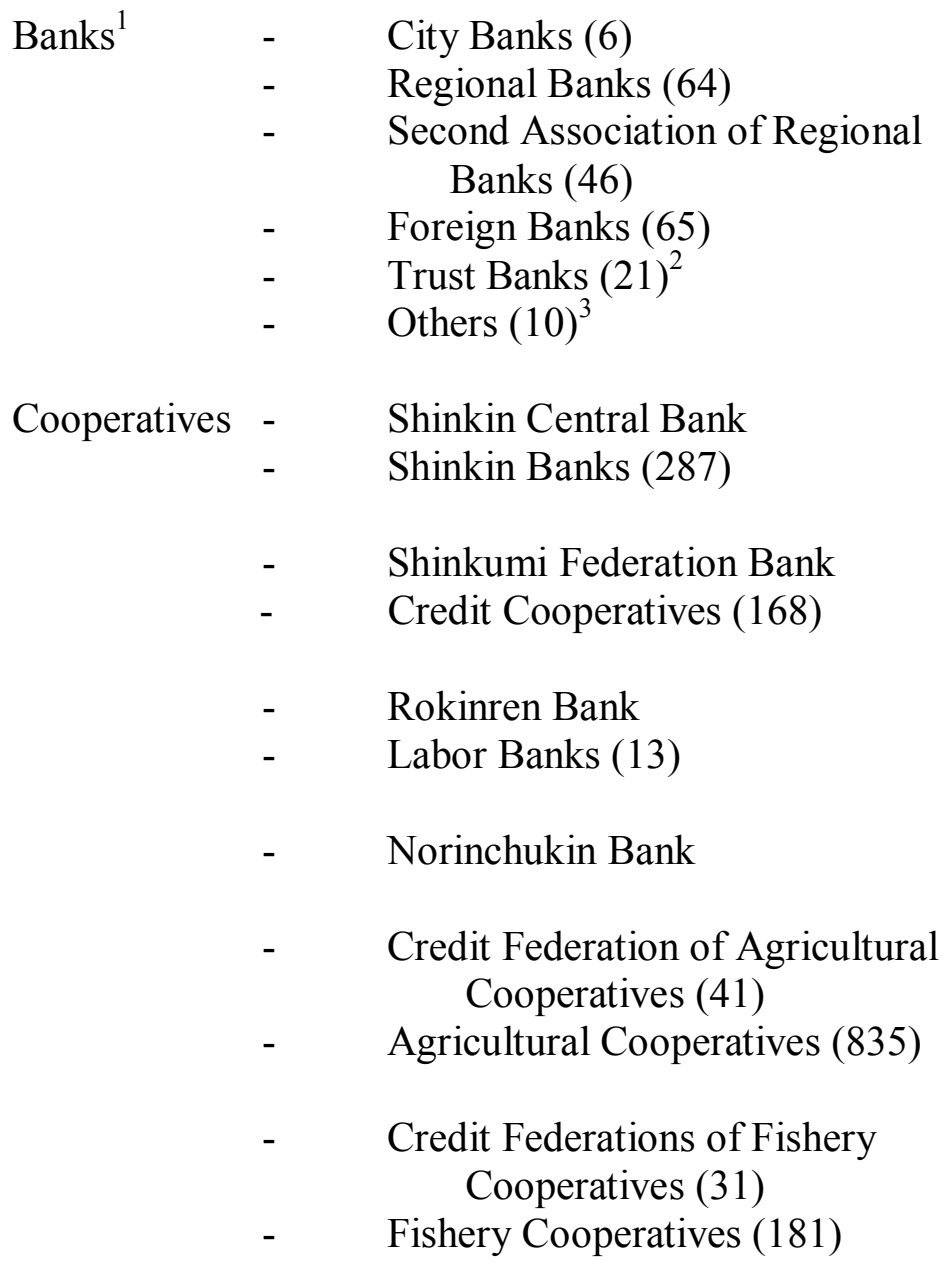

* Figures in parentheses represent the number of institutions in each category operating at 1 April 2007.

Notes: (1) Including 10 bank holding companies.

(2) Including foreign-owned trust banks.

(3) Including the Second Bridge Bank of Japan and the Resolution and Collection Corporation.

Source: Japanese Bankers' Association, 2007, p.1. 


\section{EXHIBIT 2 : CONSOLIDATION AMONGST THE MAJOR JAPANESE BANKS, 2000-2006}

\begin{tabular}{|c|c|c|c|}
\hline Merged Entities & Date of Merger & New Entity Formed & Latest Developments \\
\hline $\begin{array}{l}\text { Dai-Ichi Kangyo Bank }{ }^{(1)} \\
\text { Fuji Bank }^{(1)} \\
\text { Industrial Bank of Japan }^{(2)} \\
\text { Mizuho Trust }^{(3)} \\
\text { (jointly owned) }\end{array}$ & September 2000 & $\begin{array}{l}\text { Mizuho Holdings, } \\
\text { comprising: } \\
\text { Dai-Ichi Kangyo Bank }^{(1)} \text {; } \\
\text { Fuji Bank }{ }^{(1)} \text {; } \\
\text { Industrial Bank of Japan }{ }^{(2)} \text {; } \\
\text { Mizuho Trust }^{(3)}\end{array}$ & $\begin{array}{l}\text { Mizuho Holdings (renamed } \\
\text { Mizuho Financial Group in } \\
\text { March 2003), } \\
\text { comprising (at April 2002): } \\
\text { Mizuho Bank }{ }^{(1)} \text {; } \\
\text { Mizuho Corporate Bank }^{(1)} \text {; } \\
\text { Mizuho Trust }^{(3)}\end{array}$ \\
\hline $\begin{array}{l}\text { Sakura Bank } \\
\text { Sumitomo Bank }^{(1)}\end{array}$ & April 2001 & $\begin{array}{l}\text { Sumitomo Mitsui } \\
\text { Banking Corporation }\end{array}$ & $\begin{array}{l}\text { Sumitomo Mitsui } \\
\text { Financial Group, } \\
\text { comprising (at Dec. 2002): } \\
\text { Sumitomo Mitsui } \\
\text { Banking Corporation }^{(1)}\end{array}$ \\
\hline $\begin{array}{l}\text { Bank of Tokyo } \\
\text { Mitsubishi }^{(1)} \\
\text { - Tokyo Trust } \\
\text { Mitsubishi Trust }^{(4)} \\
\text { Nippon Trust }^{(4)}\end{array}$ & April 2001 & $\begin{array}{l}\text { Mitsubishi Tokyo } \\
\text { Financial Group, } \\
\text { comprising: } \\
\text { Bank of Tokyo- } \\
\text { Mitsubishi } \\
\text { Mitsubishi Trust }^{(4)} \text {; } \\
\text { Nippon Trust } \\
\text { Tokyo Trust }^{(3)}\end{array}$ & $\begin{array}{l}\text { Mitsubishi Tokyo Financial } \\
\text { Group, } \\
\text { comprising (at Oct. 2001): } \\
\text { Bank of Tokyo- } \\
\text { Mitsubishi }^{(1)} \text {; } \\
\text { Mitsubishi Trust }^{(4)}\end{array}$ \\
\hline $\begin{array}{l}\text { Sanwa Bank } \\
\text { Tokai Bank }^{(1)} \\
\text { - Tokai Trust } \\
\text { Toyo Trust } \\
\text { Toy }\end{array}$ & April 1001 & $\begin{array}{l}\text { UFJ Holdings, } \\
\text { comprising: } \\
\text { Sanwa Bank }{ }^{(1)} \text {; } \\
\text { Tokai Bank }{ }^{(1)} ; \\
\text { Toyo Trust } \\
\text { Tokai Trust }^{(3)}\end{array}$ & $\begin{array}{l}\text { UFJ Holdings, } \\
\text { comprising (at Jan. 2002): } \\
\text { UFJ Bank }^{(1)} \text {; } \\
\text { UFJ Trust }^{(4)}\end{array}$ \\
\hline $\begin{array}{l}\text { Daiwa Bank Holdings, } \\
\text { comprising (at Dec. 2001): } \\
\text { Daiwa Bank }^{(1)} \text {; } \\
\text { Kinki Osaka Bank }^{(5)} \text {; } \\
\text { Nara Bank }^{(5)} \text {; } \\
\text { Asahi Bank }^{(1)} \text {; } \\
\text { Asahi Trust } \\
\text { (3) }\end{array}$ & $\begin{array}{l}\text { March } 2002 \\
\text { (effective } \\
\text { October 2002) }\end{array}$ & $\begin{array}{l}\text { Resona Holdings, } \\
\text { comprising: } \\
\text { Daiwa Bank }^{(1)} \text {; } \\
\text { Asahi Bank }^{(1)} \text {; } \\
\text { Kinki Osaka Bank }{ }^{(5)} \text {; } \\
\text { Nara Bank }^{(5)} \text {; } \\
\text { Daiwa Trust }^{(4)}\end{array}$ & $\begin{array}{l}\text { Resona Holdings, } \\
\text { comprising (at March } \\
\text { 2003): } \\
\text { Resona Bank }^{(1)} \text {; } \\
\text { Saitama Resona Bank }{ }^{(1)} \text {; } \\
\text { Kinki Osaka Bank }^{(5)} \text {; } \\
\text { Nara Bank }^{(5)} \\
\text { Resona Trust }^{(4)}\end{array}$ \\
\hline $\begin{array}{l}\text { Mitsubishi Tokyo Financial } \\
\text { Group } \\
\text { UFJ Holdings }\end{array}$ & $\begin{array}{l}\text { October } 2005 \\
\text { (effective } \\
\text { January 2006) }\end{array}$ & $\begin{array}{l}\text { Mitsubishi UFJ Financial } \\
\text { Group }\end{array}$ & - \\
\hline
\end{tabular}

Notes: (1) City Bank. [In 2004 the Saitama Resona Bank was reclassified as a regional bank.]

(2) Long-Term Credit Bank.

(3) Trust Bank Subsidiary.

(4) Trust Bank.

(5) Regional Bank.

Source: Japanese Bankers' Association, 2006, p.14. 


\begin{tabular}{|c|c|c|c|c|c|c|c|c|}
\hline ஓ્ণ & $\begin{array}{l}n \\
\infty\end{array}$ & $\stackrel{?}{\forall}$ & on & חֶ. & 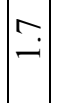 & $\begin{array}{l}0 \\
\dot{\sigma}\end{array}$ & $\underset{0}{3}$ & $\begin{array}{l}\infty \\
\dot{\nabla}\end{array}$ \\
\hline 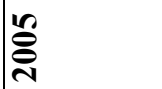 & $\mid \begin{array}{l}\infty \\
\infty\end{array}$ & $\begin{array}{c}n \\
i \\
i\end{array}$ & $\because$ & $\stackrel{⿱}{r}$ & $\stackrel{0}{i}$ & in & $\ddot{0}$ & in \\
\hline 芯 & $\stackrel{r}{\infty}$ & $\begin{array}{l}0 \\
\dot{\nabla}\end{array} \mid$ & $\vec{b}$ & $\hat{\sigma}$ & $\stackrel{\sim}{\sim}$ & $\vec{i}$ & $\vec{i}$ & $\begin{array}{l}0 \\
i\end{array}$ \\
\hline ్ֶֻలి & $\stackrel{\circ}{\circ}$ & $\stackrel{?}{\stackrel{*}{*}}$ & $\hat{6}$ & $\ddot{0}$. & 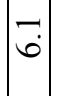 & $\because$ & $\ddot{0}$ & $\exists$ \\
\hline ర్సે & $\ddot{\sigma}$. & $\begin{array}{c}0 \\
\dot{m}\end{array} \mid$ & $\underset{r}{0}$ & : & $\stackrel{0}{r}$ & $\stackrel{0}{-1}$ & 守 & i \\
\hline હ્ڤ & 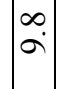 & $\vec{m}$ & $\stackrel{0}{\circ}$ & in & $\stackrel{\nabla}{\circ}$ & $\stackrel{n}{n}$ & $\underset{i}{\stackrel{r}{r}}$ & iे \\
\hline Ð્ડ & $\sigma^{\circ}$ & $\begin{array}{c}0 \\
\text { r. }\end{array}$ & $\vec{\therefore}$ & m & $\begin{array}{l}0 \\
0 \\
0\end{array}$ & $\frac{m}{T}$ & $\stackrel{\nexists}{-}$ & F. \\
\hline $\hat{\sigma}$ & $\hat{\sigma}$ & $\begin{array}{c}n \\
i\end{array}$ & $\stackrel{?}{r}$ & $\stackrel{\leftrightarrow}{\dot{f}}$ & $\begin{array}{c}m \\
0\end{array}$ & $\stackrel{+}{\top}$ & $\underset{\infty}{\infty}$ & $\stackrel{\overbrace{}}{\sim}$ \\
\hline$\stackrel{\infty}{\sigma}$ & $\left|\begin{array}{l}0 \\
\hdashline \\
\ddots\end{array}\right|$ & $\vec{m}$ & $\because$ & is & $\begin{array}{l}n \\
\sim \\
\sim\end{array}$ & 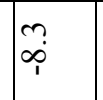 & $\stackrel{\nabla}{-}$ & $\vec{\varphi}$ \\
\hline$\hat{\sigma}$ & 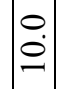 & $\begin{array}{c}0 \\
\dot{m}\end{array}$ & $\stackrel{2}{2}$ & in & $\begin{array}{l}\dot{v} \\
\stackrel{\sim}{\sim}\end{array}$ & $\stackrel{\leftrightarrow}{i}$ & 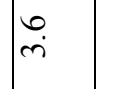 & F \\
\hline よ้ & $\begin{array}{l}\infty \\
\stackrel{0}{0}\end{array}$ & $\begin{array}{c}0 \\
\dot{m}\end{array}$ & $\left|\begin{array}{l}0 \\
\infty\end{array}\right|$ & ナे & $\stackrel{\sim}{\sim}$ & $\frac{0}{T}$ & $\stackrel{\sim}{-}$ & $\stackrel{\sim}{0}$ \\
\hline 2 & $\begin{array}{l}\infty \\
0 \\
0\end{array}$ & $\begin{array}{c}n \\
m\end{array}$ & $\stackrel{\infty}{\infty}$ & ?ֶ. & $\stackrel{\sim}{\sim}$ & $\mid \begin{array}{l}\infty \\
\dot{\varphi} \\
\dot{0}\end{array}$ & $\stackrel{ナ}{\forall}$ & $\underset{i}{\stackrel{\sim}{i}}$ \\
\hline बे & $\vec{\sigma}$ & $\overrightarrow{\mathrm{i}}$ & $\stackrel{\infty}{\infty}$ & $\stackrel{\odot}{\stackrel{\theta}{ }}$ & กู. & $\stackrel{\sim}{\sim}$ & $\stackrel{\sim}{n}$ & $\stackrel{0}{-}$ \\
\hline$\stackrel{\tilde{\sigma}}{\sigma}$ & مa & $\left|\begin{array}{l}\infty \\
i\end{array}\right|$ & $\stackrel{\infty}{\infty}$ & $\stackrel{?}{+}$ & $\stackrel{r}{\dot{\gamma}}$ & 芒 & $\stackrel{\circ}{i}$ & I \\
\hline$\tilde{\sigma}$ & $\begin{array}{l}\infty \\
\ddots \\
\sigma\end{array} \mid$ & $\begin{array}{c}n \\
\sim \\
\sim\end{array}$ & $\stackrel{r}{r}$ & $\because$ & $\begin{array}{c}0 \\
i\end{array} \mid$ & $\stackrel{n}{i}$ & 0 & $\stackrel{\sim}{\sim}$ \\
\hline $\bar{\sigma}$ & $\dot{\rho} \vec{\infty}$ & $\begin{array}{c}\sim \\
ن \\
ن\end{array}$ & $?$ & $\stackrel{n}{n}$ & $\stackrel{0}{-1}$ & $\stackrel{n}{a}$ & $\hat{o}$ & $\stackrel{m}{m}$ \\
\hline$\stackrel{2}{\sigma}$ & 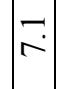 & $\begin{array}{l}0 \\
i \\
\end{array} \mid$ & 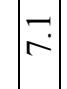 & $\underset{\sim}{\stackrel{0}{i}}$ & $\begin{array}{l}\infty \\
0 \\
0\end{array}$ & $\stackrel{\infty}{\rightarrow}$ & $\stackrel{\circ}{i}$ & $\infty$ \\
\hline 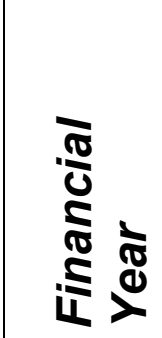 & 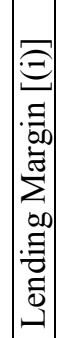 & 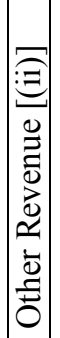 & 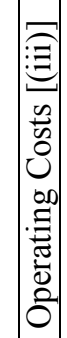 & 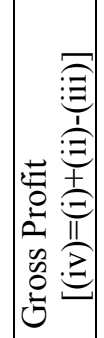 & 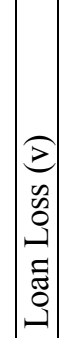 & 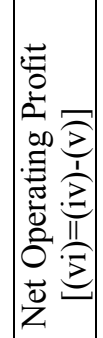 & 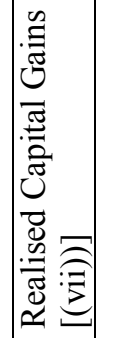 & 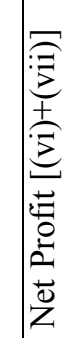 \\
\hline
\end{tabular}

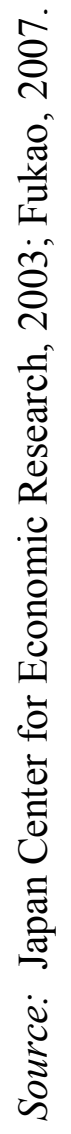




\section{EXHIBIT 4 : THE EVOLUTION OF THE "BAD" (i.e. "RISK MANAGEMENT") LOANS OF THE JAPANESE DEPOSIT-TAKING SECTOR, 1992- 2006}

\begin{tabular}{|c|c|c|c|}
\hline Date & $\begin{array}{l}\text { "Bad" Loans } \\
\text { Outstanding } \\
\text { ( } ¥ \text { billion })\end{array}$ & $\begin{array}{l}\text { Stock of Specific } \\
\text { Provisions Outstanding } \\
(\Psi \text { billion })\end{array}$ & $\begin{array}{l}\text { Estimate of "Problem } \\
\text { Loans to be Disposed of }{ }^{\prime 1} \\
(¥ \text { billion })\end{array}$ \\
\hline End of March 1992 & $7,000-8,000^{2}$ & -- & -- \\
\hline End of March 1993 & $8,400^{2}, 000$ & -- & -- \\
\hline End of March 1994 & $10,500^{2}$ & -- & -- \\
\hline End of September 1994 & $13,300^{2}$ & -- & -- \\
\hline End of March 1995 & $11,640^{2}$ & -- & -- \\
\hline End of September 1995 & $38,086^{3}$ & 6,961 & $18,587^{4}$ \\
\hline End of March 1996 & $34,799^{5,6}$ & $12,530^{5}$ & $8,305^{5}$ \\
\hline End of September 1996 & $29,228^{7,8}$ & $9,948^{7}$ & $7,303^{7}$ \\
\hline End of March 1997 & $27,900^{9,10}$ & $12,343^{9}$ & $4,685^{9}$ \\
\hline End of September 1997 & $28,078^{11,12}$ & $13,993^{11}$ & $4,348^{11}$ \\
\hline End of March 1998 & & & \\
\hline $\begin{array}{l}\text { Under "old" disclosure } \\
\text { Standards }\end{array}$ & $24,979^{13,14}$ & N.A. & N.A. \\
\hline $\begin{array}{l}\text { Under "new disclosure" } \\
\text { Standards }\end{array}$ & $35,207^{13,14}$ & $19,035^{13}$ & $1,583^{13,15}$ \\
\hline End of March 1999 & 38,656 & 14,802 & N.A. \\
\hline End of March 2000 & $41,367^{16}$ & $11,500^{16}$ & N.A. \\
\hline End of March 2001 & $43,448^{17}$ & $10,039^{17}$ & N.A. \\
\hline End of March 2002 & $53,049^{18}$ & $10,375^{18}$ & N.A. \\
\hline End of March 2003 & $45,676^{18}$ & $8,569^{18}$ & N.A. \\
\hline End of March 2004 & 35,851 & 7,775 & N.A. \\
\hline End of March 2005 & 25,840 & 6,384 & N.A. \\
\hline End of March 2006 & 20,284 & 4,583 & N.A. \\
\hline End of March 2007 & 18,354 & 4,297 & N.A. \\
\hline
\end{tabular}

Notes:

1. This figure represents an estimate by the Ministry of Finance of the scale of loans for which possible losses have not been provided nor that are likely to be covered by collateral (i.e. loan losses considered "irrecoverable" and not provided for).

2. Ministry of Finance estimate of "nonperforming loans" for the 21 largest banks. Figures include claims against customers who went bankrupt and claims on which interest payments were more than six months overdue due to the suspension of interest payments, but exclude "restructured loans" (i.e. those on which interest payments have been cut) and the bad debts of affiliates.

3. Figures include "restructured loans" (i.e. loans on which interest rates have been reduced to below the ruling official discount rate) for the first time and now cover all Japanese deposit-taking financial institutions (i.e. city banks, long-term credit banks, trust banks, regional banks and co-operatives).

4. The figure is inclusive of possible losses (estimated at $¥ 7,700$ billion) resulting from exposure to the eight jusen companies.

5. The figures exclude the Kizu Cooperative (with about $¥ 1,190$ billion in problem loans), the Fukui Prefecture First Credit Cooperative ( $¥ 2.6$ billion), the Osaka Credit Cooperative ( $¥ 270$ billion), and Taiheiyo Bank ( $¥ 330$ billion).

6. The figure excludes loans to borrowers to which the lending bank(s) is extending help (including forgiving loans), estimated at $¥ 3,795$ billion for all "major" banks (i.e. excluding regional banks and co-operatives) at end of March 1996.

7. Loans to jusen companies are excluded, as are the Kizu Credit Cooperative (with approximately $¥ 1,190$ billion in problem loans), the Osaka Credit Cooperative ( $¥ 270$ billion), the Kenmindaiwa Credit Cooperative ( $¥ 15$ billion), and Sanyo Credit Cooperatives ( $¥ 17$ billion). 
8. The figure excludes loans to borrowers to which the lending bank is extending help (including forgiving loans), estimated at $¥ 3,724$ billion for all "major" banks (i.e. excluding regional banks and cooperatives) at end of September 1996.

9. The figures exclude the Hanwa Bank (with around $¥ 190$ billion in problem loans), the Sanpuku Credit Cooperative ( $¥ 26$ billion), and the Hanshin Labor Credit Cooperative ( $¥ 3.5$ billion).

10. The figure excludes loans to borrowers to which the lending bank(s) is extending help (including forgiving loans), estimated at $¥ 3,373$ billion at end of March 1997 for all "major" banks (i.e. excluding co-operatives but including regional banks for the first time).

11. The figures exclude the Hokkaido Takushoku Bank, Hanwa Bank, Hanshin Labor Credit Cooperative, Tokai Credit Cooperative, Toki Credit Cooperative, Kitakyushu Credit Cooperative, Kanagawa Credit Cooperative, Tanabe Credit Cooperative, and the Choginosaka Credit Cooperative.

12. The figure excludes loans to borrowers to which the lending bank(s) is extending help, estimated at $¥ 3,084$ billion at end of September 1997 for all major banks (as defined in note 10).

13. The figures exclude the Hokkaido Takushoku Bank, Tokuyo City Bank, Kyoto Kyoei Bank, Naniwa Bank, Fukutoku Bank, Midori Bank, and 32 credit companies whose assets and liabilities have been transferred to other institutions.

14. The figure excludes loans to borrowers to which the lending bank(s) is extending help, estimated at $¥ 2,015$ billion at end of March 1998 for all Japanese deposit-taking institutions.

15. The figure was provided privately to me by the FSA.

16. The figures exclude the Nippon Credit Bank.

17. The figures include the Nippon Credit Bank but exclude the Tokyo Sowa Bank, Niigata Chuo Bank and bankrupted co-operatives.

18. The figures exclude financial institutions which were declared bankrupt.

Sources: Hall, 2000; Financial Supervisory/Services Agency (various). 


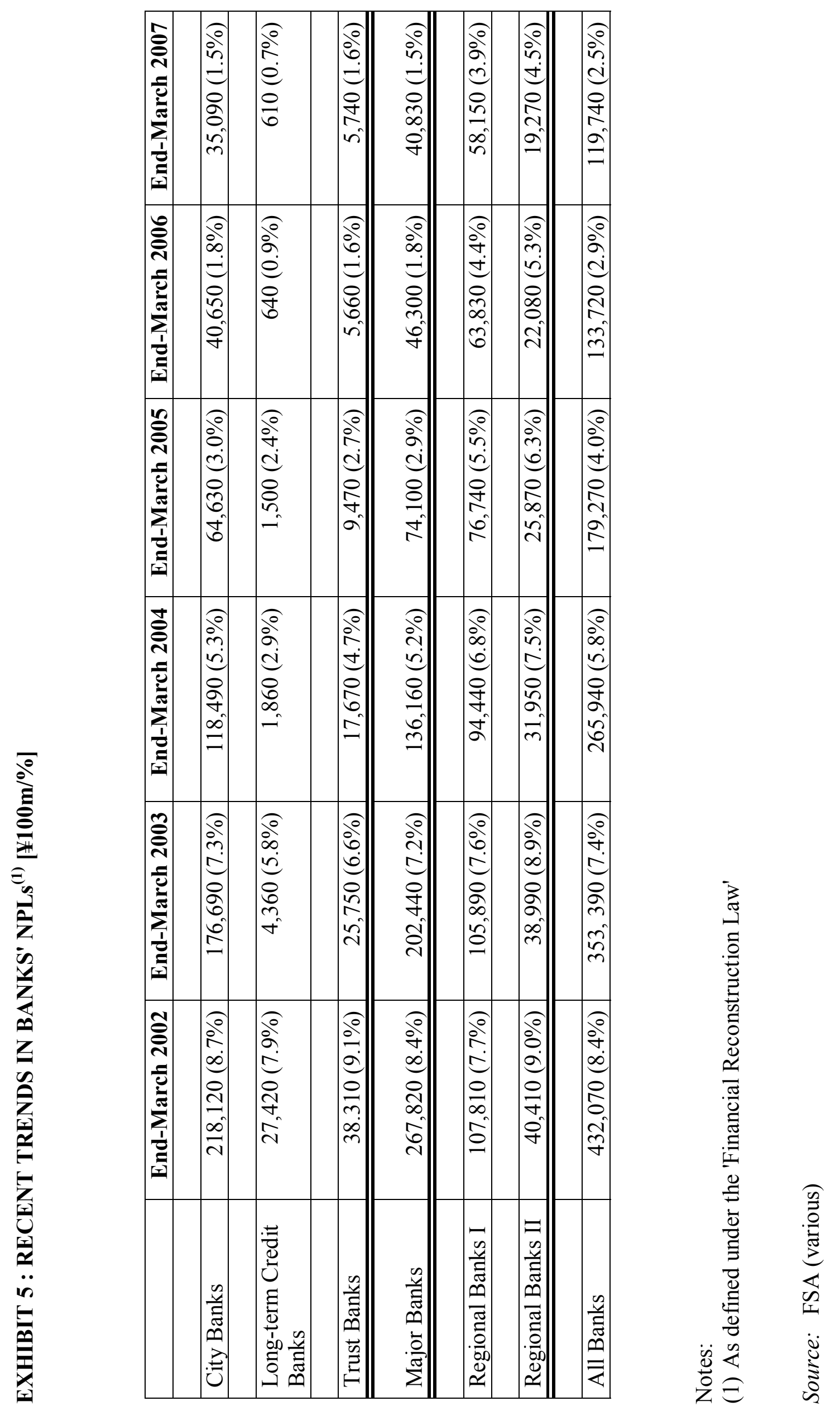




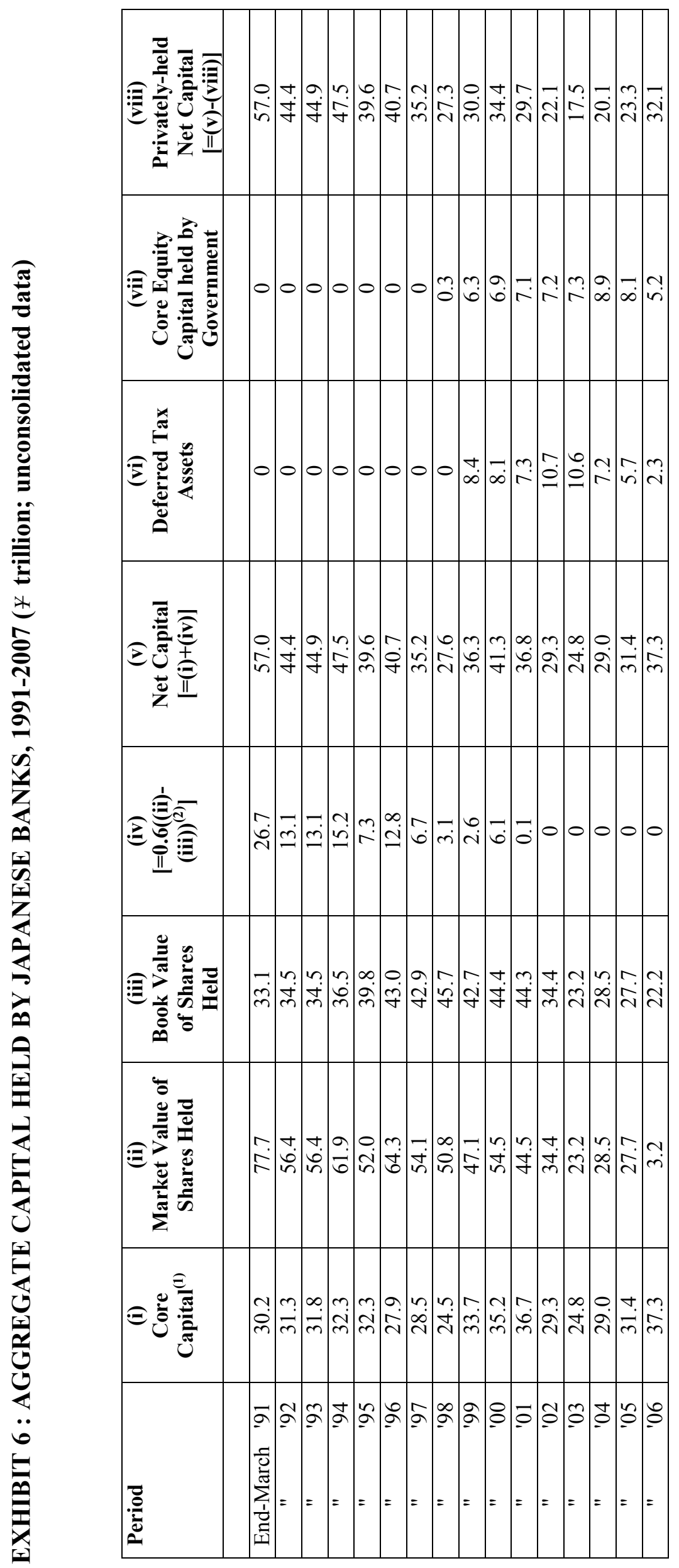

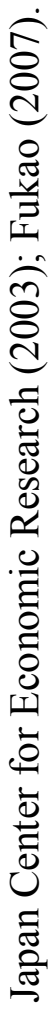

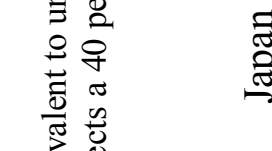

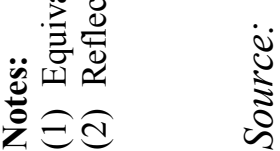

